\title{
Model experiments and simulations on influence of liquefaction on scour at a landward toe of coastal dykes due to tsunami overflow
}

\author{
N. Takegawa, Y. Sawada, K. Murai, T. Kawabata \\ Graduate School of Agricultural Science, Kobe University, Kobe, Hyogo, Japan
}

\begin{abstract}
In the 2011 off the Pacific Coast of Tohoku Earthquake, massive tsunami caused serious damage to coastal dykes. One of the failure mechanisms of a coastal dyke has been considered as the local scour at the landward toe of a coastal dyke. Furthermore, there is a possibility that liquefaction occurs around a coastal dyke by aftershocks when tsunami strikes. In this paper, flume experiments were conducted to clarify the influence of liquefaction on the scour at a landward toe of coastal dykes due to tsunami over flow. Moreover, simulations were conducted to evaluate the influence of the upward seepage on the scour. In the experiments, scour process and scour profile is different according to the degree of liquefaction. In the simulations, the vertical velocity at the bottom of scour hole increases by the upward seepage. However, there is little influence of the vertical velocity on the scour because the uplift force of the vertical velocity is small.
\end{abstract}

\section{INTRODUCTION}

On March 11, 2011, the 2011 off the Pacific coast of Tohoku Earthquake caused enormous damage, and the earthquake triggered massive tsunami. The tsunami caused severe damage to coastal dykes and seawalls. From the field surveys by Kato et al. (2012), one of the failure mechanisms of a coastal dyke has been considered as the local scour at the landward toe of a coastal dyke as shown in Figure 1. Moreover, it was found from the hydraulic data at Choshi offshore that tsunami and the largest aftershock may occur simultaneously (Fukumoto et al., 2012). This study indicates the possibility that liquefaction occurs when tsunami strikes.

Many studies on the scour at the landward toe have been conducted. Mitobe et al. (2014) conducted hydraulic model experiments to understand characteristics of the local scour at the landward toe and showed the different characteristics of the scour process by different kinds of hydraulic jump. Hatogai et al. (2008) and Iiboshi et al. (2015) examined the scour process and the effects of landward protection.

In the previous studies, experiments and analyses on wave-induced liquefaction have been also conducted (Nagano \& Maeno, 1987; Zen \& Yamazaki, 1990; Sassa \& Sekiguchi, 1999). The rapidly decreasing water level brings the pore water pressure gradient, and the pore water pressure gradient causes a decrease in the effective stress. When tsunami backwash comes, the water level rapidly decreases. Therefore, it is likely that a decrease in the effective

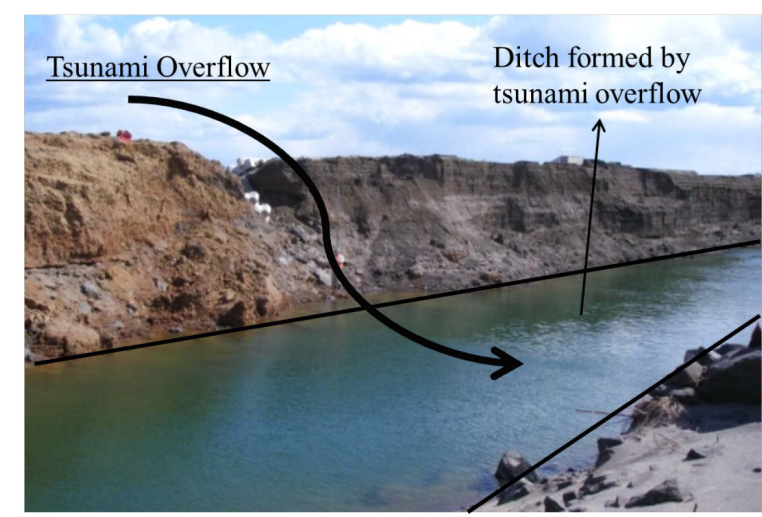

Figure 1. Local scour at landward toe (modified from Kato et al., 2012).

stress and liquefaction will be caused by tsunami backwash. Actually, Sawada et al. (2014) pointed out from the wave data that liquefaction occurred under the condition that amplitude of changes in sea level was large and the drawdown rapidly occurred.

Although studies on the scour by tsunami, liquefaction by the earthquake and wave-induced liquefaction have been conducted as described above, the combined effects of liquefaction and the scour by tsunami are poorly known. Moreover, in future, a large scale earthquake with a magnitude of around 8 (referred to as the Tokai-Nankai Earthquake) is expected to occur in Japan with a high probability within 30 years. Therefore, countermeasures against tsunami disaster by the earthquake are important, and it is necessary to clarify the influence of liquefaction on the scour at the landward toe of coastal dykes. 
On the basis of the above mentioned background, in this paper, flume experiments were conducted to clarify the influence of liquefaction on the scour. Liquefaction was controlled by the upward seepage. Moreover, the upward seepage actually occurs in the ground when the pore water pressure dissipates in the process of liquefaction. There is a possibility that the scour is affected by the upward seepage. Therefore, simulations were conducted to evaluate the influence of the upward seepage on the scour. In order to evaluate the influence of the upward seepage, difference in the velocity due to presence and absence of the upward seepage was investigated.

\section{EXPERIMENTAL SETUP}

\subsection{Experimental apparatus}

Figure 2 shows the schematic diagram of the experimental apparatus. The flume is $2.0 \mathrm{~m}$ long and 0.3 $\mathrm{m}$ wide and made of acrylic to observe the scour process. The sand bed is $0.5 \mathrm{~m}$ long, $0.3 \mathrm{~m}$ wide and $0.2 \mathrm{~m}$ high, and three pore water pressure gauges were placed on the acrylic wall. In the experiment, liquefaction was controlled by the upward seepage. The upward seepage was induced by the head difference between the water tank and the sand bed. The hydraulic gradient of the sand bed is given as $i(=H$ $/ L$ ). In Figure 2 (b), $H$ is the difference in total head, and $L$ is the height of sand bed. The hydraulic gradient of the sand bed depends on elevation of the water tank. As a coastal dyke model, the 1:2 slope $(0.2$ $\mathrm{m}$ long, $0.1 \mathrm{~m}$ high, $0.3 \mathrm{~m}$ wide) was installed.

\subsection{Experimental conditions}

Silica sand was used in the experiment. The silica sand was washed with water and sieved with a 75 $\mu \mathrm{m}$ screen to eliminate fine fractions. The properties

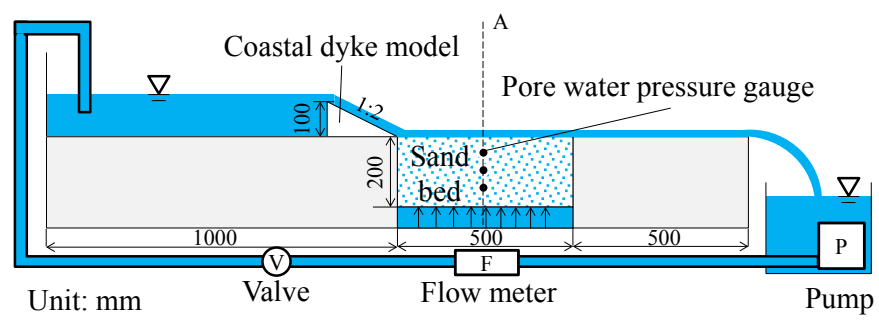

(a) Side view of apparatus except water tank.

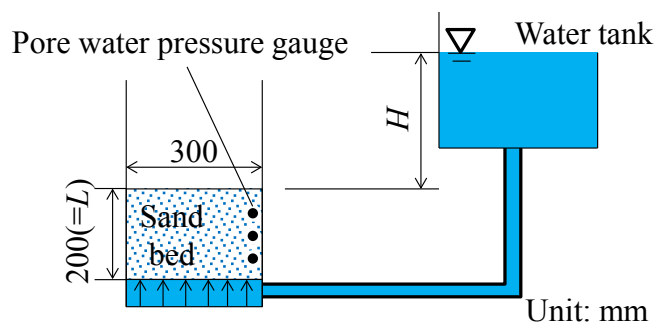

(b) Cross section of $\mathrm{A}$.

Figure 2. Experimental apparatus. of the silica sand are shown in Table 1. The saturated sand bed was prepared by the water pluviation method. Experimental conditions were shown in Table 2. A pump was used to circulate the water, and the flow rate was controlled by a regulating valve and a flowmeter. The scour process and the scour profile were recorded by a video camera. The maximum scour depth and the scour length were determined from the image captured by the video camera as shown in Figure 3.

Table 1. Properties of silica sand.

\begin{tabular}{ll}
\hline Density of soil particle $\rho_{\mathrm{s}}\left[\mathrm{g} / \mathrm{cm}^{3}\right]$ & 2.63 \\
\hline Maximum dry density $\rho_{\max }\left[\mathrm{g} / \mathrm{cm}^{3}\right]$ & 1.64 \\
\hline Minimum dry density $\rho_{\min }\left[\mathrm{g} / \mathrm{cm}^{3}\right]$ & 1.30 \\
\hline $50 \%$ grain size $D_{50}[\mathrm{~mm}]$ & 0.30 \\
\hline Relative density $[\%]$ & $25-35$ \\
\hline Uniformity index $U_{\mathrm{c}}$ & 2.14 \\
\hline
\end{tabular}

Table 2. Experimental conditions.

\begin{tabular}{|c|c|c|c|}
\hline \multicolumn{2}{|c|}{ Series 1} & \multicolumn{2}{|c|}{ Series 2} \\
\hline $\begin{array}{l}\text { Hydraulic } \\
\text { gradient } i\end{array}$ & Flow rate $q$ & $\begin{array}{l}\text { Hydraulic } \\
\text { gradient } i\end{array}$ & Flow rate $q$ \\
\hline 0.0 & \multirow{6}{*}{$\begin{array}{c}0.5 \\
(1 / s)\end{array}$} & 0.0 & \multirow{6}{*}{$\begin{array}{c}1.0 \\
(1 / s)\end{array}$} \\
\hline 0.2 & & 0.2 & \\
\hline 0.4 & & 0.4 & \\
\hline 0.6 & & 0.6 & \\
\hline 0.8 & & 0.8 & \\
\hline 1.0 & & 1.0 & \\
\hline
\end{tabular}

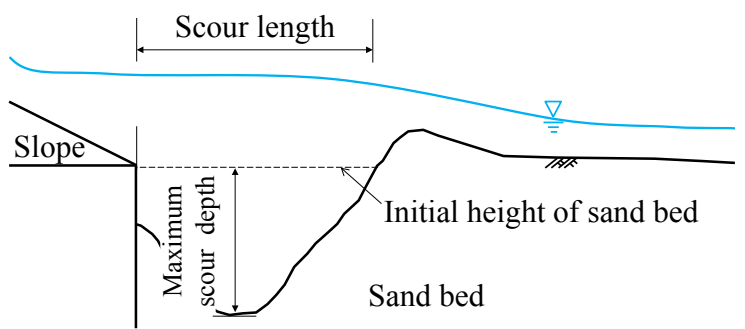

Figure 3. Definition of maximum scour depth and scour length.

\subsection{Upward seepage and excess pore pressure}

Figure 4 shows the relationship between the hydraulic gradient and the flow rate of the upward seepage. It is observed that the flow rate of the upward seep-

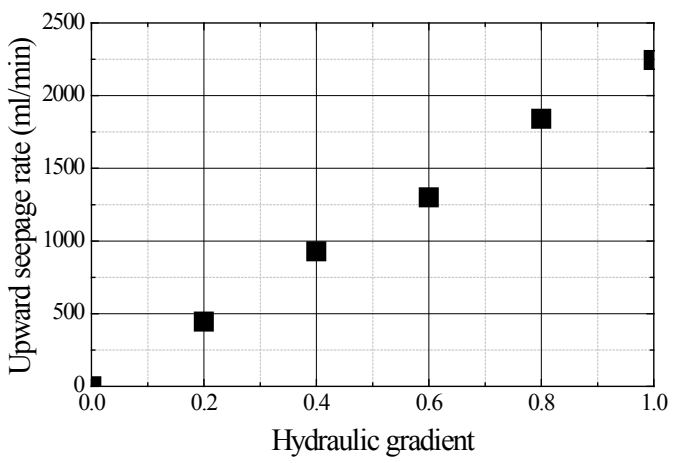

Figure 4. Relationship between hydraulic gradient and upward seepage. 
age increases linearly with the hydraulic gradient.

Figure 5 shows the relationships between the excess pore water pressure and the depth from the sand bed. The effective overburden pressure was calculated from the submerged unit weight. The excess pore pressure increases with increase in the hydraulic gradient and is equal to the effective burden pressure at $i=1.0$. The result shows that the effective stress of the sand bed and liquefaction can be controlled by the hydraulic gradient. Note that the critical hydraulic gradient calculated by Terzaghi equation approximately is equal to 0.85 .

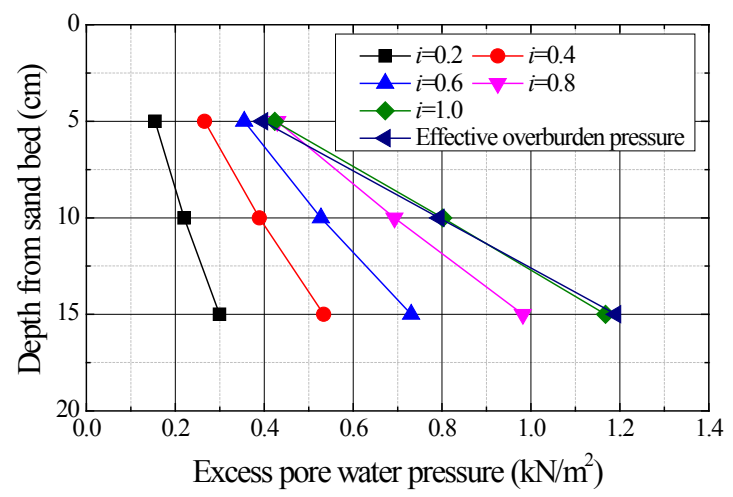

Figure 5. Relationships between excess pore water pressure and depth from sand bed.

\section{EXPERIMENTAL RESULTS AND DISCUSSION}

\subsection{Influence of liquefaction at initial stage of scour $(0 \sim 10 \mathrm{~s})$}

In the subsection, the scour profiles at the initial stage $(0 \sim 10 \mathrm{~s})$ are described for Series $2(q=1.0 \mathrm{~L} / \mathrm{s})$. Figure 6 shows the scour profiles at $1 \mathrm{~s}$ for $i=0.0$ and $i=1.0$. It is found from Figure 6 that the scour profile is completely different between $i=0.0$ and $i=1.0$. In $i=0.0$, the scour hole is formed in a semicircular shape. In $i=1.0$, the scour hole is formed in an elongated shape and inclined obliquely. The trend is seen only for $i=1.0$.

Figure 7 shows the scour profiles at $7 \mathrm{~s}$ for $i=0.0$ and $i=1.0$. In addition, the scour profiles at $8 \mathrm{~s}$ and 9 $\mathrm{s}$ are shown in Figure 7 with dashed lines. In $i=0.0$, the scour hole develops while maintaining the semicircular shape in the initial $1 \mathrm{~min}$. In contrast to $i=0.0$, the surface shape of the sand bed changes incessantly in $i=1.0$. The undulating surface of the sand bed is observed. Furthermore, the slope at the downstream part of the scour hole is almost vertical. The trend is seen from $i=0.6$ to $i=1.0$.

\subsection{Scour profiles at each hydraulic gradient $(i=$ $0.0 \sim 1.0)$}

Figure 8 shows the scour profiles at $30 \mathrm{~s}$ for Series 1 $(q=0.5 \mathrm{~L} / \mathrm{s})$ and Series $2(q=1.0 \mathrm{~L} / \mathrm{s})$. In Figure 8,
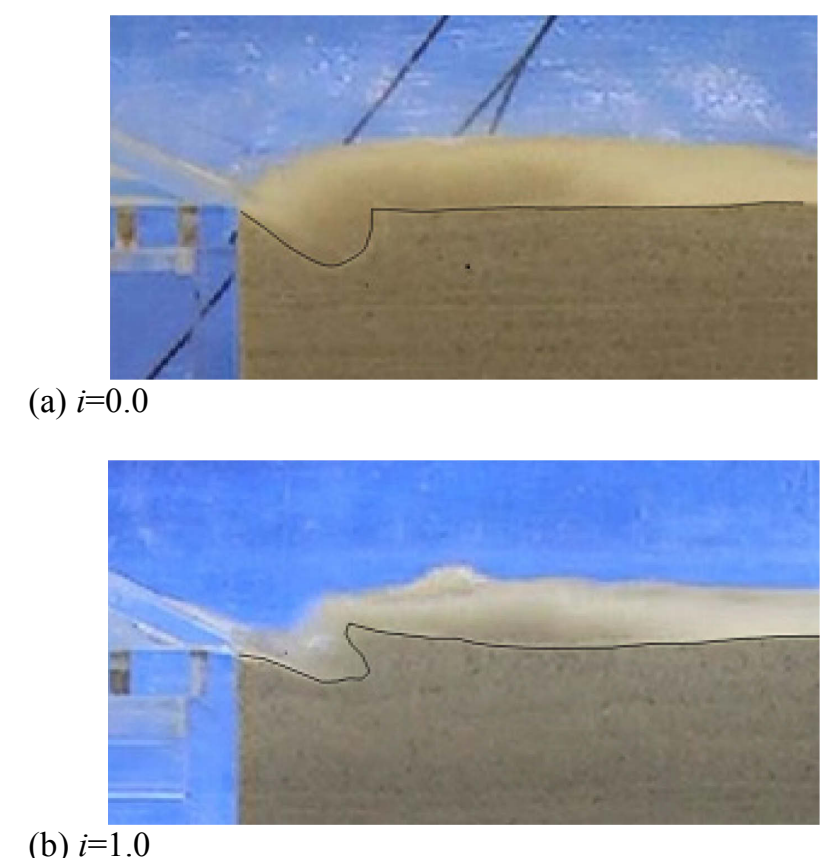

Figure 6. Scour profiles at $1 \mathrm{~s}$ for $i=0.0$ and $i=1.0$.

(a) $i=0.0$
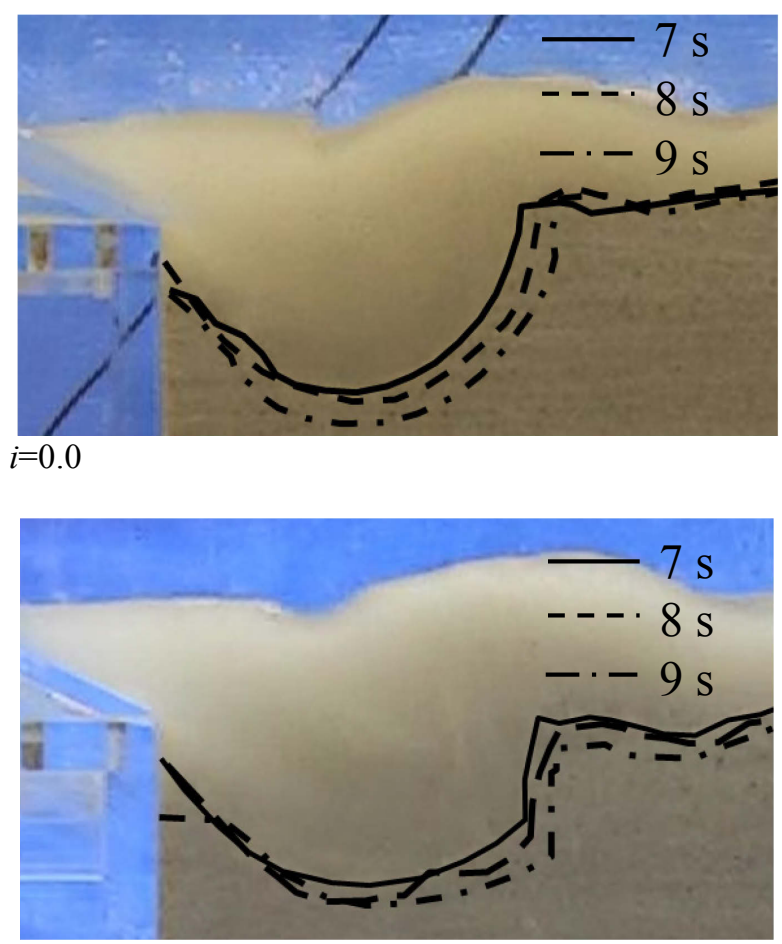

(b) $i=1.0$

Figure 7. Scour profiles at $7 \mathrm{~s}, 8 \mathrm{~s}$ and $9 \mathrm{~s}$ for $i=0.0$ and $i=1.0$.

with increase in the hydraulic gradient, the scour hole expands downstream, and the maximum scour depth decreases. This trend can be attributed to the slope failure by the decrease in the effective stress. Slope stability is determined by the balance of shear stress and shear strength. Shear strength becomes smaller with the decrease in the effective stress, and the sediment under low effective stress conditions behaves like fluid. It is observed in the experiment that the sediment deposited around the scour hole behaves like fluid, and the slope failure at the downstream part of the scour hole and the expansion of 
the scour hole occur at high hydraulic gradient. As a result, the sediment is deposited at the scour hole. In summary, the scour profile at high hydraulic gradient become shallower and wider than the scour profiles at low hydraulic gradient.

The expansion of the scour hole by liquefaction is distinctive as described above. Therefore, the change of the scour length at each hydraulic gradient is described in the paragraph. The change of the scour length with progress of time is shown in Figure 9. In Series 1 and Series 2, when the hydraulic gradient is equal to 1.0, the rate of the increase in the scour length is obviously high at the initial stage of the scour. This can be attributed to liquefaction. When the hydraulic gradient is less than 0.8 , the sand bed is not liquefied completely as shown in Figure 5, and the bed shear strength is held in some degree. As a result, when the hydraulic gradient is less than 0.8 , there is little difference in the scour length at the initial stage of scour. When the hydraulic gradient is equal to 1.0, the sand bed is liquefied completely. Therefore, the sand bed behaves like fluid, and the scour length increases rapidly by the slope failure.

\section{INFLUENCE OF UPWARD SEEPAGE ON SCOUR}

\subsection{General outline}

In this paper, the upward seepage was used to reproduce liquefaction. Moreover, the upward seepage actually occurs in the ground when the pore water pressure dissipates in the process of liquefaction. There is a possibility that the scour is affected by the upward seepage. Therefore, in order to evaluate the influence of the upward seepage on the scour, simulations were conducted. In the present simulation, difference in the velocity due to presence and absence of the upward seepage was investigated.

For the above purpose, CADMAS-SURF (SUper Roller Flume for Computer Aided Design of MArine Structure) was used for the simulation. CADMASSURF is a numerical simulation of wave-making flume and commonly used for the design of facilities in sea areas. CADMAS-SURF can simulate incompressible flow with free surface using a finite differential method based on the Navier-Stokes equation.

\subsection{Outline of simulation}

\subsubsection{Analytical conditions}

Figure 10 shows the initial configuration for the simulation. The horizontal and vertical mesh size were set as $\Delta x=0.5 \mathrm{~cm}$ and $\Delta y=0.5 \mathrm{~cm}$. The flume, the coastal dyke model and the bed model in the simulation are the same size as the present experiment. The coastal dyke model consists of a nonpermeable structure, and the bed model consists of a

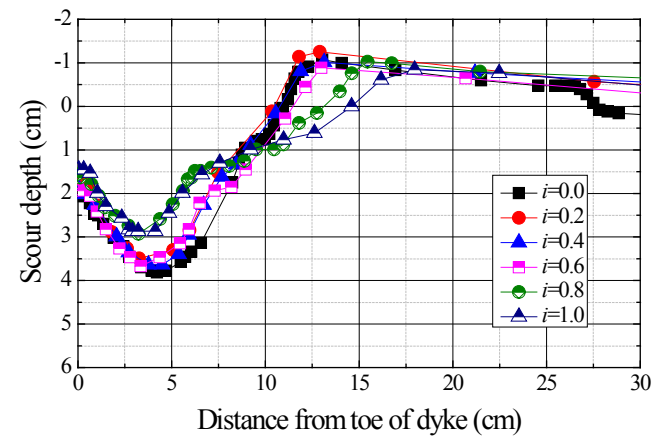

(a) Series $1(q=0.5 \mathrm{~L} / \mathrm{s})$

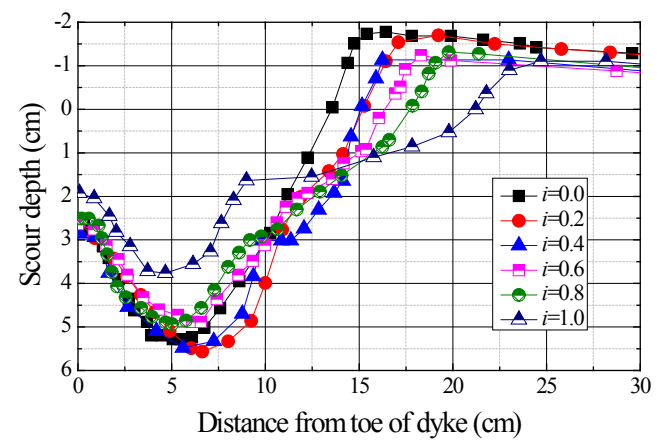

(b) Series $2(q=1.0 \mathrm{~L} / \mathrm{s})$

Figure 8. Scour profiles at $30 \mathrm{~s}$ for Series $1(q=0.5 \mathrm{~L} / \mathrm{s})$ and Series $2(q=1.0 \mathrm{~L} / \mathrm{s})$.

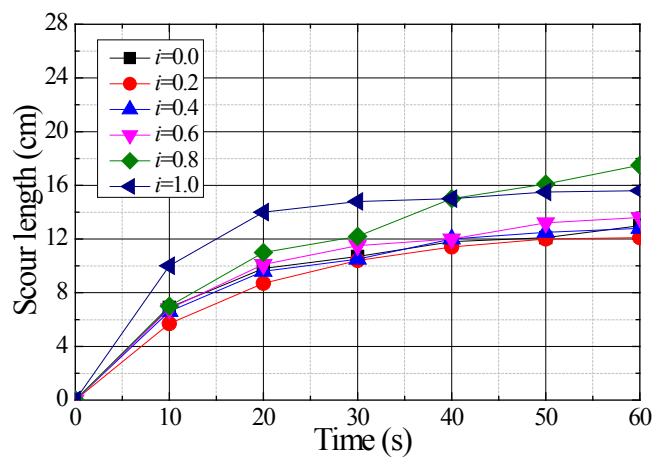

(a) Series $1(q=0.5 \mathrm{~L} / \mathrm{s})$

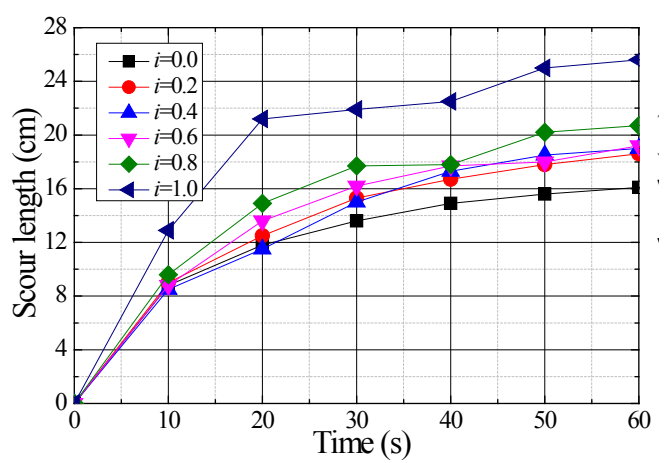

(b) Series $2(q=1.0 \mathrm{~L} / \mathrm{s})$

Figure 9. Change of scour length with progress of time.

permeable structure. The bed model is described in detail in the next sub-subsection.

The analytical conditions and parameters used in the simulation are shown in Table 3 and Table 4. The water was generated from the inflow boundary. The flow rate of $1.0 \mathrm{~L} / \mathrm{s}$ was applied so that the flow 
rate was the same as the experiment of Series 2 $(q=1.0 \mathrm{~L} / \mathrm{s})$. In Figure 4, the flow rate of the upward seepage is equal to $2250 \mathrm{ml} / \mathrm{min}$ at $i=1.0$. Therefore, in Case 1 (with upward seepage), the flow rate of the upward seepage was determined as $2250 \mathrm{ml} / \mathrm{min}$. the upward seepage was generated from the bottom of the bed model as shown in Figure 10. In order to evaluate influence of the upward seepage of the scour, the horizontal velocity and the vertical velocity at the bottom of the scour hole were outputted. The direction of arrow in Figure 10 expresses the direction of positive velocity.

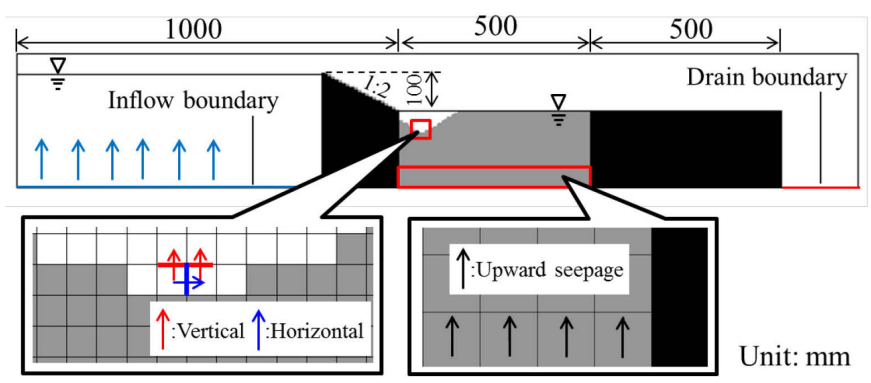

Figure 10. Initial configuration and measurement point.

Table 3. Analytical conditions.

\begin{tabular}{ll}
\hline Test Case & Condition \\
\hline Case 1 & With upward seepage \\
\hline Case 2 & Without upward seepage \\
\hline
\end{tabular}

Table 4. Parameters used in the simulation.

\begin{tabular}{ll}
\hline Time increment & Auto \\
\hline calculation time & $10 \mathrm{~s}$ \\
\hline$\Delta x$ & $0.5 \mathrm{~cm}$ \\
\hline$\Delta y$ & $0.5 \mathrm{~cm}$ \\
\hline Turbulence model & $\mathrm{k}-\varepsilon$ model \\
\hline Kinematic viscosity coefficient & $1.0 \times 10^{-6} \mathrm{~m}^{2} / \mathrm{s}$ \\
\hline Difference scheme & Donor-1.0 \\
\hline Boundary condition of pressure & Slip \\
\hline Boundary condition in VOF method & Free \\
\hline Porosity of the permeable structure & 0.47 \\
\hline Coefficient of inertia & $1.0 \times 10^{3}$ \\
\hline Drag coefficient & $3.0 \times 10^{5}$ \\
\hline
\end{tabular}

\subsubsection{Bed model}

Scour process cannot be reproduced by CADMASSURF. It is necessary to determine a scour profile, and the scour profile at $60 \mathrm{~s}$ captured from the experiment $(i=0.0, q=1.0 \mathrm{~L} / \mathrm{s})$ was used in the present simulation.

In CADMAS-SURF, characteristics of the permeable structure are determined by three parameters, porosity of the permeable structure, a coefficient of inertia and a drag coefficient. The porosity was calculated as about 0.47 from the experimental condition.

There are no reference values in regards to the coefficient of inertia and the drag coefficient. Thus, the two parameters were determined by trial and error so that the experimental pore water pressure was reproduced when the upward seepage was applied to the bed model. Figure 11 shows relationships between pore water pressure and depth from the sand bed. It can be observed that the simulated result is in good agreement with the experimental data.

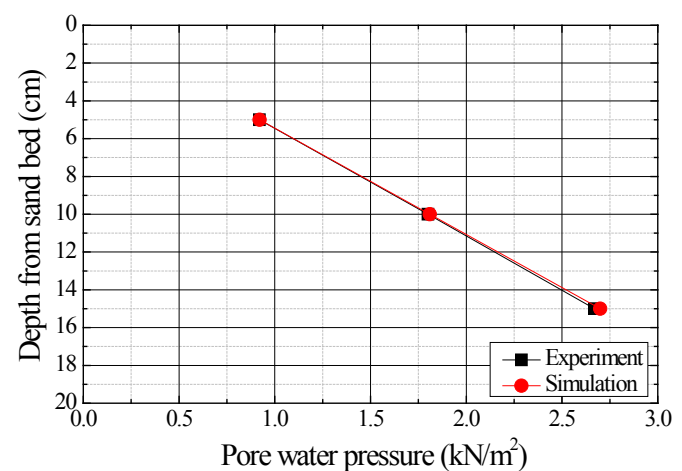

Figure 11. Relationships between pore water pressure and depth from sand bed.

\subsection{Results and discussion}

The comparison of the horizontal velocity at the bottom of the scour hole between Case 1 (with upward seepage) and Case 2 (without upward seepage) is shown in Figure 12. The horizontal velocity at the bottom of the scour hole fluctuates unsteadily in the initial stage of simulation because the water level is unstable. Therefore, the velocity at the bottom of scour hole was outputted after water level becomes stable. In Figure 12, there is little difference between Case 1 and Case 2. It can be seen that the upward seepage does not affect the horizontal velocity. Figure 13 shows comparison of the vertical velocity at the bottom of the scour hole. The clear difference between the Case 1 and Case 2 can be observed. The vertical velocity in Case 1 is larger than Case 2. These results show that although the horizontal velocity at the bottom of the scour hole is not affected by the upward seepage, the vertical velocity at the bottom of the scour hole is affected by the upward seepage. However, uplift force that a sand particle experiences from the upward seepage calculated by Stokes equation is smaller than submerged weight of the particle. Therefore, the influence of the vertical velocity on the scour is small.

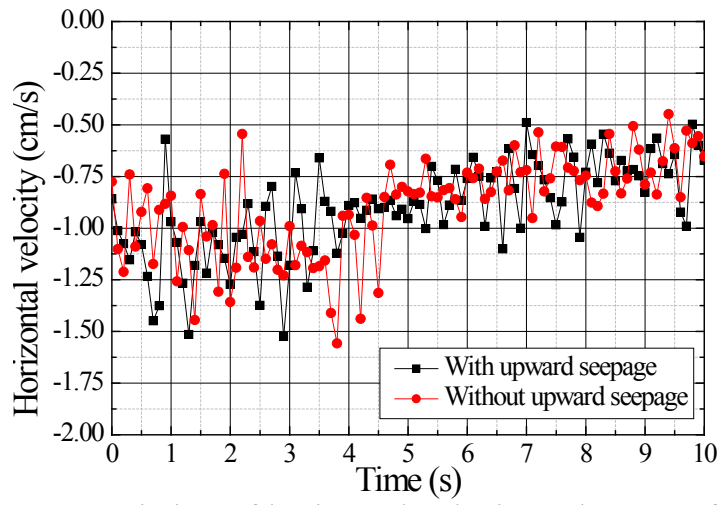

Figure 12. Variation of horizontal velocity at bottom of scour hole. 


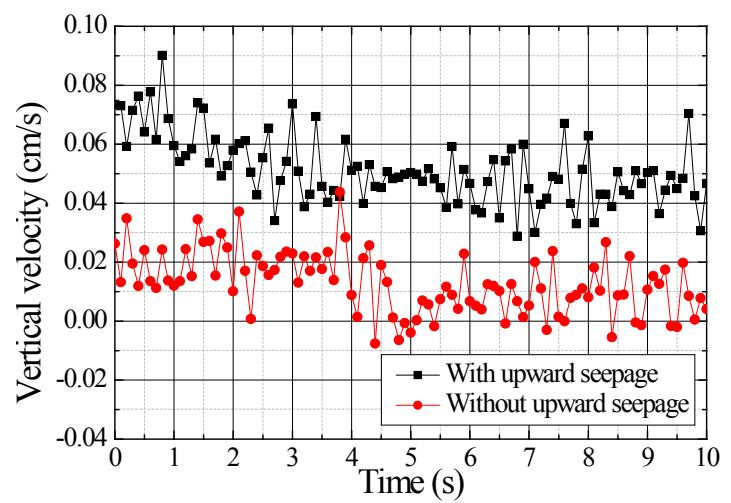

Figure 13. Variation of vertical velocity at bottom of scour hole.

\section{CONCLUSIONS}

In order to clarify the influence of liquefaction on the scour at the landward toe of coastal dykes due to tsunami overflow, flume experiments were conducted. In the experiment, liquefaction was controlled by the upward seepage which changes depending on the hydraulic gradient $(i=0.0 \sim 1.0)$. Moreover, the numerical simulations were conducted to evaluate the influence of the upward seepage on the scour. As a result, the following conclusions were obtained.

1. The scour profile at $1 \mathrm{~s}$ for $i=0.0$ is formed in a semicircular shape. In contrast to $i=0.0$, the scour profiles at $1 \mathrm{~s}$ for $i=1.0$ is formed in an elongated shape and inclined obliquely.

2. The surface shape of the sand bed changes incessantly in the initial $1 \mathrm{~min}$ when $i=1.0$. The undulating surface of the sand bed is observed. Furthermore, the slope at the downstream part of the scour hole is almost vertical.

3. At high hydraulic gradient, the sediment deposited around the scour hole flows like fluid. As a result, the slope failure occurs and the scour hole expands downstream. The sediment is deposited at the scour hole by the slope failure, and the maximum depth decreases. when the hydraulic gradient is equal to 1.0 , the rate of the increase in the scour length is obviously high at the initial stage of the scour.

4. The horizontal velocity at the bottom of the scour hole is not affected by the upward seepage. On the other hand, the vertical velocity is affected by the upward seepage. However, uplift force that a sand particle experiences from the upward seepage calculated by Stokes equation is smaller than submerged weight of the particle. Therefore, the influence of the vertical velocity on the scour is small.
In this paper, the simulation under specific condition was conducted. Therefore, as future work, we plan to change analytical conditions such as a flow rate of overtopping water, size of the scour hole and a scour profile, and examine influence of the upward seepage on the scour.

\section{ACKNOWLEDGEMENT}

The work reported here was supported by JSPS Grant-in-Aid for Young Scientists (B) No.15K18758.

\section{REFERENCES}

Fukumoto, Y., Sukegawa, H., Iwamae, N., and Ikeya, T. 2012. The 2011 off the Pacific coast of Tohoku Earthquake tsunami hydraulic data observed at Choshi offshore. Journal of Japan Society of Civil Engineers 69(2): 1-5 (in Japanese).

Hatogai, S., Suwa, Y., and Kato, F. 2008. Hydraulic model experiments on scour landward of the coastal dike induced by tsunami overflow. Journal of Japan Society of Civil Engineers 68(2): 406-410 (in Japanese).

Iiboshi, T., Maeno, S., Yosida, K., Takata, D., and Yamaura, A. 2015. Effects of landward slope protection and toe protection work shape at coastal dikes on landward bed scouring caused by tsunami overflow. E-proceedings of the 36th IAHR World Congress. Hague, Netherlands.

Kato, F., Suwa, Y., Watanabe, K., and Hatogai, S. 2012. Mechanisms of coastal dike failure induced by the Great East Japan earthquake tsunami. Proceedings of the 33rd International Conference on Coastal Engineering. Santander, Spain.

Mitobe, Y., Adityawan, M.B., Tanaka, H., Kawahara, T., Kurosawa, T., and Otsushi, K. 2014. Experiment on local scour behind coastal dikes induced by tsunami overflow. Proceedings of the 34th International Conference on Coastal Engineering. Seoul, Korea.

Nagao, H. and Maeno, S. 1987. Pore pressure and effective stress in a highly saturated sand bed under water pressure variation on its surface. Journal of Natural Disaster Science 9(1): 23-25.

Sassa, S., and Sekiguchi, H. 1999. Wave-induced liquefaction of beds of sand in a centrifuge. Geotechnique 49(5): 621638.

Sawada, Y., Miyake, M., Sumida, H., and Kawabata, T. 2014. Pore water pressure and liquefaction in saturated sand bed induced by tsunami. IDRE Journal 290: 55-62.

Zen, K., and Yamazaki, H. 1990. Oscillatory pore pressure and liquefaction in seabed induced by ocean waves. Soils and Foundations 30(4): 147-161. 